\title{
Analysis of Law Enforcement to Drugs Criminal Act in Military Environment (Case Study in Jurisdiction of Military Court II/09 Bandung)
}

\begin{abstract}
Asep Suherdin ${ }^{1}$ and Maryanto ${ }^{2}$
Abstract. The problems of this study are: 1) How is enforcement against members of the military in drug abuse in the jurisdiction of the Military Court II/09 Bandung? 2) How constraints and efforts to overcome the constraints of law enforcement against members of the military in drug abuse in the jurisdiction of the Military Court II/09 Bandung?

Method sociological approach juridical law and specification in this study were included descriptive analysis. Even the sources and types of data in this study are primary data obtained from interviews with field studies Military Court II/09 Bandung, and secondary data obtained from the study of literature. Data were analyzed qualitatively. The problems studied by the theory of law enforcement, criminal liability and progressive law.

Results of the discussion concluded: Enforcement of the law against members of the military in drug abuse in the jurisdiction of the Military Court II/09 Bandung executed in accordance with the applicable regulations, because the urine test is done not in accordance with regulations and charges denied by the defendant who has the right of refusal. The obstacles are the lack military justice, the need for strengthening of the system of criminal law enforcement in the military justice ahead of independent both institutionally and functionally, free from interference by other institutions outside the judiciary as a logical consequence system of a democratic constitutional state, so it is necessary No reconstruction of the existing regulation of military justice. Next to the military justice system, particularly related to the investigation should be conducted by military police consisting of the Army, Navy and Air Force, independently.

Keywords: Law Enforcement; Crime; Drugs; Military Environment.
\end{abstract}

\section{Introduction}

Unitary Republic of Indonesia is a constitutional state based on Pancasila and the Constitution of 1945, this provision contained in the Act of 1945 which states that: "Indonesia is a country based on law (rechstaat), not based on power (machstaat). With the law so any cases that arise in the life of society can be resolved through the court process mediated by a judge under the provisions of applicable law. Criminal law enforcement efforts realized through the Criminal Justice System. ${ }^{3}$

Each has absolute competence, thus implicitly the judicial environment may not be entered and interference from other jurisdictions. The General Courts and Military Courts (also of the Religious and Administrative Courts) each stand-alone functions and absolute authority, can not be interfered by other jurisdictions. ${ }^{4}$

\footnotetext{
${ }^{1}$ Student of Master of Law, Universitas Islam Sultan Agung Semarang and Members of Indonesian Army, Email: asepsuherdin6@gmail.com

2 Lecturer of Master of Law, Faculty of Law, UNISSULA, Semarang

${ }^{3}$ Abdussalam and DPM Sitompul, 2007, Sistem Peradilan Pidana, Restu Agung, Jakarta, p. 4.

${ }^{4}$ Augustine $\mathrm{PH}$, Prospecting and Urgency Interrogation of connectivity in the Journal of Military Law, Volume I 2 November 2007 (Jakarta: Center for the Study of Military Law STHM, 2007) p. 96. The same
} 
In the military world narcotics often necessary to treat wounds for military members affected fired in order to dissipate the pain of the suffering members of the military. Narcotics needed by humans for treatment so as to meet the needs in the field of medicine and scientific studies required an ongoing narcotics production to misery. In weighing the basis of Act No. 35 of 2009 on narcotics mentioned that narcotics on one side is a drug or useful materials in the field of medicine or health services and the development of science and on the other hand can also cause dependency highly detrimental if they are misused or used without strict control and supervision and care. Narcotics when used on an irregular basis according to dose / dose will have cause physical and mental harm to those who use it and can dependency on the users themselves. That is a very strong desire to use the psychological nature of the drug continuously for emotional reasons ${ }^{5}$,

In fact, many members of the military who committed a crime one of them is abuse of narcotics (drugs). Indonesian law stipulates that no citizen is immune to the law, even though the offense is committed by civilians and members of the military. When crimes are committed by civilians following the completion process of the civil procedural law set out in the Criminal Code. When members of the military do a Crime, it will still be convicted without any privileges, begin the process of inspection, investigation, and prosecution until the court will follow the procedural law of military justice as stipulated in Act No. 31 of 1997 on Military Justice.

Each member of the military must obey and adhere to the provisions of law applicable to the military that the Military Criminal Law Act Code (KUHPM), Military Justice Law, Law on Military Discipline Code (KUHDM) Military Disciplinary Code (PDM) and other regulations related to the military. Nevertheless, the submission of the military to the citizens of the KUHPM not necessarily be said to be their legal dualism ${ }^{6}$,

Based on the background of the above problems, the problem is formulated as follows:

- How law enforcement against members of the military in drug abuse in the jurisdiction of the Military Court II/09 Bandung?

- How constraints and efforts to overcome the constraints of law enforcement against members of the military in drug abuse in the jurisdiction of the Military Court II/09 Bandung?

The approach used in this study is a sociological juridical approach. Sociological juridical approach is to identify and conceptualize law as a social institution that is real and functional in a real life system. ${ }^{7}$ The nature of the research is descriptive analysis.

thing Harkristuti Harkrinowo, in his paper that the existence of Military Justice of the above, it is expressly stated that the distinguishing criterion for determining the competence of this Court vis a vis other court focused on the subject or the offender. Some are based on the subject (Military Justice), there is the type of case (State Administration), and some are based on the case or the subject (the Religious Courts). By determining the subject of the perpetrator as a point of differentiation, the Military Court is entitled to examine the cases allegedly committed by persons subject to military law. See Harkristuti Harkrisnowo, "Kewenangan Penyidikan atas Pelanggaran Hukum oleh Anggota Polri: Kini dan Esok," (Paper in Seminar Sehari Militer, Polisi dan Penegakan Hukum di Indonesia, Hold by Yayasan Studi Perkotaan and Jurnal Urbania Jakarta, 13 February 2001) p.6.

${ }^{5}$ Hadi Setia Tunggal. 2013. PerUndang-Undang Narkotika Dan Psikotropika Terbaru, Harryando. Jakarta, p. 29.

${ }^{6}$ Erdianto 2010, Pokok-Pokok Hukum Pidana, Alaf Riau, Pekanbaru, p. 23.

${ }^{7}$ Soerjono Soekanto, 1986, Pengantar Penelitian Hukum, University of Indonesia Press, Jakarta, p. 51. 
According to Whitney, the descriptive method is the fact finding with the correct interpretation. ${ }^{8}$ The purpose of descriptive research is to describe precisely, the nature of the individual, a symptom, condition or specific groups.

\section{Results and Discussion}

\subsection{Act Enforcement Against Military Members in Jurisdiction of Military Court II/09 Bandung}

Military environment must be free of all personal conduct that are bad and reprehensible, but because the TNI members also are human beings, who can not be separated from negligence or emotional sense as other men, but it is also member of the military in his life also socialize with the people around so still allowing unaffected negative things. Possibility to engage with the misuse of narcotics was as big as the possibilities that exist in society in general.

In the military world narcotics often necessary to treat wounds for military members affected fired in order to dissipate the pain of the suffering members of the military. Narcotics needed by humans for treatment so as to meet the needs in the field of medicine and scientific studies required an ongoing narcotics production to misery. In weighing the basis of Act No. 35 of 2009 on narcotics mentioned that narcotics on one side is a drug or useful materials in the field of medicine or health services and the development of science and on the other hand can also cause dependency highly detrimental if they are misused or used without strict control and supervision and care. Narcotics when used on an irregular basis according to dose / dose will have cause physical and mental harm to those who use it and can dependency on the users themselves. That is a very strong desire to use the psychological nature of the drug continuously for emotional reasons ${ }^{9}$.

Jurisdiction (Jurisdiction or Rechtmacht a check or prosecuting authority) and Yustisiabel (Justisiabel) are people who are subject or subordinated to the control of a specific judicial body actually belong to the field of procedural law piadana in a broad sense. Studying the jurisdiction of a judicial body also means at the same time learn Yustisiabel of these jurisdictions. In this paper held second decomposition splitting the material, because of the close relationship with the material criminal law (in the subject as an element of an offense) is about Yustisiabel. ${ }^{10}$ Jurisdiction and Yustisiabel are two terms that are mutually complementary. Thus the provisions on jurisdiction can also be interpreted as the provisions regarding Yustisiabel.

As a commander of a military unit can submit the case (law) relating to members who committed the crime to the Military Court, while the process of the investigation conducted by POM. Instead as Ankum, a unit commander has only duties to be applied in the unity and security management is done by the department of POM. ${ }^{11}$

\footnotetext{
${ }^{8}$ Soejono and Abdurahman, 1999, Metode Penelitian, Rieneka Citra, Jakarta, p. 21

${ }^{9}$ Hadi Setia Tunggal. 2013. Perundang-Undangan Narkotika Dan Psikotropika Terbaru, Harryando, Jakarta, p. 29.

${ }^{10}$ SR Sian, 1985, Hukum Pidana Militer di Indonesia, Alumni AHM-PTHM, Jakarta, p. 21.

${ }^{11}$ Results Interview with Col. Chk (K) Nanik Suwarni, SH., MH, as Head of Military Court II-09 Bandung, on 19 February 2020 at 14.15 pm
} 
By determining the subject of the perpetrator as a point of differentiation, the military court is entitled to examine the cases allegedly committed by persons subject to military law. With the separation of military subjects in the process of settlement of criminal acts done as stipulated in Article 2 of Act No. 39 of 1947 concerning the Code of Military Criminal Law, does not result in the lackof disorderly among military and also does not interfere with the order of law in the society at large. ${ }^{12}$

Based on the foregoing, it can happen lack in the military justice system, in which one side of the military justice as the executor of judicial power independently, on the other hand put the role of non-judicial bodies in the organizational structure of the judiciary as well as in processes / procedures of law enforcement, including coaching organizational, administrative, financial and personnel development.

\subsection{Constraints and Law Enforcement Efforts to Overcome Obstacles Against Military Members In Narcotics Abuse In Court Jurisdiction II/09 Bandung}

Criminal accountability is accountability by the people against the criminal act committed. In essence, criminal liability is a mechanism built by the criminal law to react to the deal refused a certain action. ${ }^{13}$ Reject the agreement may be written rules and unwritten rules that were born and developed in the community. Written rules of accountability for perpetrators of criminal acts of drug abuse both civilian and military has been clearly stipulated in the regulations, among other Act No. 35 of 2009 on Narcotics.

Likewise the evidence of serious TNI Commander to keep his soldiers to not fall to the abuse of drugs, the TNI Commander Telegram issued Letter No. STR / 398/2009 dated July 22, 2009 as noted above. It certainly has a strong foundation, as a TNI soldier exposed to narcotics, it is doubtful that they can keep a good job, especially if it was on the battlefield, is not impossible that soldiers exposed to narcotics would endanger other soldiers, he said soldiers have been exposed to drugs could endanger its unity and other soldiers, so it was fitting that a TNI soldier exposed to narcotics must be removed from their units through dismissal. ${ }^{14}$

Law enforcement Constraints against members of the military in drug abuse, it should be considered to reflect Progressive law which rejects any notion that the legal institution as an institution which has the final and absolute, otherwise progressive law believe that legal institutions are in a state of becoming. ${ }^{15}$

Constraints in processing the soldiers through the military justice system is the existence of the military justice, The philosophy of the independently in the military justice system due to: 1) Factor interests of the military (TNI) that are associated with the main task of TNI defend national sovereignty, so that using force commander role (Ankum) and Armed institutions within the law enforcement system; 2)The objections

\footnotetext{
${ }^{12}$ Results Interview with Col. Chk (K) Nanik Suwarni, SH., MH, as Head of Military Court II-09 Bandung, on 19 February 2020 at 14.15 pm

${ }^{13}$ Chairul Huda, 2011. From Dari 'Tiada Pidana Tanpa Kesalahan'menuju kepada'Tiada Pertanggung Jawaban Pidana Tanpa Kesalahan', Kencana, Jakarta, p. 71.

${ }^{14}$ Results Interview with Col. Chk (K) Nanik Suwarni, SH., MH, as Head of Military Court II-09 Bandung, on 19 February 2020 at 14.15 pm

${ }^{15}$ Ibid.
} 
of the military against the placement of the civil administration in the system of law enforcement for the military that was originally the head of the district court in the jurisdiction of the Military Courts army because of his position, becomes chairman of the court-martial, as well as the clerk of the district court because his position became clerk of court-martial, the chief state prosecutor who because of his position can be set as a judge advocate. These objections based on the grounds that the system is not profitable for the military or unity, for it must be attempted reconstruction of the regulations governing the military justice system in force today, because it would impede law enforcement against soldiers who were charged with criminal offenses in general and especially against soldiers who are exposed to narcotics.

\section{Closing}

\subsection{Conclusion}

- Happened independently in the military justice system, in which one side of the military justice as the executor of judicial power independently, on the other hand put the role of non-judicial bodies in the organizational structure of the judiciary and in-process / law enforcement procedures, including organizational development, administrative, financial, and coaching personnel.

- Constraints in processing the soldiers through the military justice system is the existence of the military justice. The philosophy of the independently in the military justice system due to: 1) Factor interests of the military (TNI) that are associated with the main task of TNI defend national sovereignty, so that using force commander role (Ankum) and Armed institutions within the law enforcement system; 2) The objections of the military against the placement of the civil administration in the system of law enforcement for the military that was originally the head of the district court in the jurisdiction of the Military Courts army because of his position, becomes chairman of the court-martial, as well as the clerk of the district court because his position became clerk of court-martial, the chief state prosecutor who because of his position can be set as a judge advocate. These objections based on the grounds that the system is not profitable for the military or unity, for it must be attempted reconstruction of the regulations governing the military justice system in force today, because it would impede law enforcement against soldiers who were charged with criminal offenses in general and especially against soldiers who are exposed to narcotics.

\subsection{Suggestion}

- Need for strengthening the system of criminal law enforcement in the military justice ahead of independent both institutionally and functionally, free from interference by other institutions outside the judiciary as a logical consequence system of a democratic constitutional state, so it needs no reconstruction on the regulation of military justice there and the future authority of the court is no longer based on the rank defendant, as well as judges, prosecutors, defense counsel, which convenes no longer use the rank but wearing a toga. Development of organizational, administrative, financial and military courts fully under the Supreme 
Court like other courts consistently implemented as stipulated in the law of judicial authority.

- Particularly related to the investigation should be conducted by military police consisting of the Army, Navy and Air Force, independently, and is responsible to the Commander of the Military Police of the Indonesian National Army. Prosecution and transfer of a case to court carried out independently by the Military Judge Advocate, and responsible to General of the Indonesian National Army.

\section{References}

[1] Abdussalam and DPM Sitompul, 2007, Sistem Peradilan Pidana, Restu Agung, Jakarta,

[2] Chairul Huda, 2011. Dari 'Tiada Pidana Tanpa Kesalahan'menuju kepada'Tiada Pertanggung Jawaban Pidana Tanpa Kesalahan', Kencana, Jakarta

[3] Erdianto, 2010, Pokok-Pokok Hukum Pidana, Alaf Riau, Pekanbaru

[4] Hadi Setia Tunggal. 2013. PerUndang-Undang Narkotika Dan Psikotropika Terbaru, Harryando. Jakarta

[5] Soejono and Abdurahman, 1999, Metode Penelitian, Rieneka Citra, Jakarta

[6] Soerjono Soekanto, 1986, Pengantar Penelitian Hukum, University of Indonesia Press, Jakarta

[7] SR Sian, 1985, Hukum Pidana Militer di Indonesia, Alumni AHM-PTHM, Jakarta 